\title{
Allelopathic effect of two medicinal plants on seed germination, seedling growth and grain production of purslane (Portulaca oleraceae $\mathbf{L}$.) weed
}

\author{
Seyed Nader MOUSAVIAN ${ }^{1}$, Hamdollah ESKANDARI ${ }^{2}$
}

Received July 24, 2017; accepted July 08, 2018.

Delo je prispelo 24. julija 2017, sprejeto 08. julija 2018.

\begin{abstract}
A laboratory factorial $(2 \times 5)$ experiment was carried out based on completely randomized block in four replications to evaluate the effect of plant species and concentration of their allelopathic extracts on seed germination and seedling growth of purslane weed (Portulaca oleraceae L.). The first factor studied was plant species (Artemisia sieberi and Salvia syriaca) and the second one the concentration percentage of plant ethanol extract $(0.0,5 \%, 10 \%, 15 \%$ and $20 \%)$. The effect of Artemisia on germination reduction of purslane was stronger compared to Salvia. The results indicated that higher extract concentration led to decreased germination percentage, germination speed and seedling growth indices of purslane including leaf length, leaf number, leaf width, leaf dry mass, stem mass and stem length. The effect of Artemisia was higher than that of Salvia. In a complementary experiment, the effect plant residues of Artemisia and Salvia (0.0, 1, 2, 3 and $4 \mathrm{~g} \mathrm{~kg}^{-1}$ soil) were evaluated in a factorial experiment base on completely randomized block design with three replications. The results of field experiment showed that plant residues significantly $(\mathrm{P} \leq 0.01)$ reduced capsule number per plant, seed number per capsule, seed production and shoot dry mass, while its effect on 1000-seed mass was not substantial. The effect of plant species and the interaction of plant species and their allelopathic extracts concentration had no major impact on the above-mentioned properties. The increase in plant residues in soil, led to the reduction of growth and seed production of purslane induced by plant number per unit area and capsule per plant. Artemisia sieberi Bess. and Salvia syriaca L. residues can be successfully used for non-chemical control of purslane weed.
\end{abstract}

Key words: allelopathy; Artemisia sieberi Bess.; Salvia syriaca L.; germination speed; seedling growth; seed production
IZVLEČEK

\author{
ALELOPATSKI UČINEK DVEH ZDRAVILNIH \\ RASTLIN NA KALITEV SEMEN, RAST SEJANK IN \\ PRODUKCIJO SEMEN NAVADNEGA TOLŠČAKA \\ (Portulaca oleraceae L.)
}

$\mathrm{Za}$ ovrednotenje učinka dveh rastlinskih vrst in koncentracije njunih alelopatskih izvlečkov na kalitev semen in rast sejank navadnega toščaka (Portulaca oleraceae L.) je bil izveden laboratorijski bločni faktorski poskus s štirimi ponovitvami. Prvi preučevani dejavnik sta bili rastlinski vrsti (Artemisia sieberi in Salvia syriaca), drugi koncentracija njunega etanolnega izvlečka v odstotkih $(0,0,5 \%, 10 \%, 15 \%$ in $20 \%)$. Učinek pelina (Artemisia) na zmanjšanje kalitve tolščaka je bil močnejši v primerjavi z učinkom kadulje (Salvia). Izsledki so pokazali, da so večje koncentracije izvlečka vodile $\mathrm{k}$ zmanjšanemu odstotku kalitve, manjši hitrosti kalitve in k zmanjšanju rastnih parametrov sejank tolščaka kot so dolžina in širina lista, število listov, suha masa listov in stebla in dolžina stebla.V komplementarnem poljskem poskusu so bili učinki ostankov obeh vrst $(0,0,1,2,3$ in $4 \mathrm{~g} \mathrm{~kg}^{-1}$ tal) ovrednoteni $\mathrm{v}$ faktorskem bločnem poskusu $\mathrm{s}$ tremi ponovitvami. Rezultati tega poljskega poskusa do pokazali, da so ostanki obeh vrst značilno $(\mathrm{P} \leq 0.01)$ zmanjšali število glavic na rastlino, število semen na glavico, produkcijo semena in suho maso poganjkov tolščaka, a vpliv na maso 1000 -semen ni bil značilen. Učinek rastlinske vrste in njene interakcije $s$ koncentracijo alelopatskih izvlečkov na zgoraj navedene parametre $\mathrm{v}$ tem poskus ni imel večjega vpliva. Povečevanje ostankov obravnavanih vrst $\mathrm{v}$ tleh je vodilo $\mathrm{k}$ zmanjšani rasti in zmanšani produkciji semena navadnega tolščaka zaradi zmanjšanja števila rastlin na enoto površine in zmanšanega števila glavic na rastlino. Ostanki obeh vrst (Artemisia sieberi Bess., Salvia syriaca L.) bi se lahko uspešno uporabljali za nekemično zatiranje navadnega tolščaka.

Ključne besede: alelopatija; Artemisia sieberi Bess.; Salvia syriaca L.; hitrost kalitve; rast sejank; produkcija semena

\footnotetext{
1 Instructor, Department of Agriculture, Payame Noor University, Tehran, Iran: *corresponding author: nader_mosavian@yahoo.com

2 Associate Professor, Department of Agriculture, Payame Noor University, Tehran, Iran
} 


\section{INTRODUCTION}

Weeds compete with crops for environmental resources such as solar radiation, soil moisture and nutrient, leading to the reduction of crop growth and yield (Cavigelli et al., 2009; Gherekhloo et al., 2010). Therefore, the initial goal of weed management in agroecosystems is reducing their negative effects on crop plants (Holander et al., 2007). Although chemical control is a simple and effective weed control measure, increased weed resistance to herbicides, public health and negative consequences of herbicides uses on environment such as surface water pollution and harmful to other organisms, concern the increased use of herbicides in production systems as well (Demden \& Liewellyn, 2006; Yuan-Quan et al., 2012). For this reason, an effort to eliminate the use of synthetic herbicides has been a growing trend. However, utilizing some non-chemical methods have limitations. Use of mechanical methods, rely heavily on the availability of machinery, whereas hand weeding cannot be implemented in all plants and needs a lot of labor as well (Kropff \& Walter, 2000). The use of a method that can reduce competitive ability and growth and development of weed seedlings at early growth stages has been emphasized (Holander et al., 2007). Employing allelopathic properties of medicinal plants is a way to achieve this goal (Ghomi \& Tavili, 2012).

Allelopathic compounds, which can be applied as nonsynthetic chemical control of weeds, provide the possibility of introducing a new generation of weed inhibitors, reducing the costs of crop production (Ghorbanli et al., 2008). According to International Allelopathy Association, allelopathy is defined as any process in which the secondary metabolites produced by plants affect the growth and development of biological systems (Gholami et al., 2011). The leaves and roots are important sources of allelopathic compounds (Jefferson $\&$ Pennachio, 2003). However, all parts of the plant may have allelopathic compounds. For example, Samad et al., 2008 observed that the extracts of all parts of five weed species had allelopathic effect on maize and reduced its growth and yield (Samad et al., 2008).
Portulaca oleraceae L., hereafter referred to as 'purslane', is a summer weed from Portulacaceae family that is able to grow in different environmental conditions. In some crop plants, such as sesame, bean and mung bean whose early seedling growth is slow, purslane damage is high, indicating the importance of timely purslane control. Purslane population can be reduced through allelopathic effects of medicinal plants. Salvia syriaca L., hereafter referred to as 'salvia', is a biennial herbaceous plant which has allelopathic compounds (Hassanpour \& Azizi, 2007). Artemisia sieberi, Bess, hereafter referred to as 'artemisia', is a perennial herb from Asteraceae family with the height of $25-50 \mathrm{~cm}$ whose secondary metabolites prevent it from grazing by livestock (Moghimi, 2005). It has been reported that many herbaceous species are not able to grow in the vicinity of Artemisia sieberi (Ghorbanli et al., 2008).

Researches have shown that medicinal plants have allelopathic properties. Ghomi \& Tavili (2012) reported that Salvia sclarea L. extract decreased germination and seedling growth of blue grass (Bromus tectorum L.), where higher concentration of plant extract showed stronger inhibitory effect on the weed growth. They also indicated that allelopathic effect of roots was higher compared to shoot extract. Behdad et al., (2008) showed that the reduction of Bromus germination resulted from allelopathic effects of Artemisia sieberi. Jafarpour et al., (2011) evaluated the allelopathic effect of residue powder of Salvia syriaca and Artemisia sieberi on bean and observed that bean germination and seedling growth were reduced. Germination percentage and speed as well as stem length and root length of orchard grass (Dactylis glomerata L.) were also negatively affected by Artemisia sieberi extract (Gholami et al., 2011).

The present experiment aimed at assessing the allelopathic effects of extract and whole plant remains of Artemisia sieberi and Salvia syriaca on germination, seedling growth and grain production of purslane.

\section{MATERIALS AND METHODS}

The current study was conducted in both laboratory and field. In the laboratory test, Artemisia sieberi and Salvia syriaca extract was prepared in the concentrations of 0.0 (control), 5.0\%, $10.0 \%, 15.0 \%$ and $20.0 \%$ and their effects on germination properties of purslane weed (including germination speed, germination percentage and seedling growth) were evaluated. A completely randomized design with four replications was employed. After collecting and drying, the samples (whole plant parts of Artemisia sieberi and Salvia syriaca ) were ground by electrical mill. Afterwards, 100 grams of ground sample were placed in a two-liter beaker and $1000 \mathrm{ml}$ of ethanol $(96.5 \%)$ were added to it and stirred with a shaker for 24 hours. The obtained solution was passed through a filter paper and its alcohol was evaporated by a rotavapor. Next, different 
concentrations (according to experimental samples) were prepared using distilled water and kept refrigerated (Samadani \& Baghestani, 2001).

Seeds of purslane were disinfected with sodium hypochlorite solution (1\%) to prevent fungal damage. Subsequently these seeds were rinsed three times with distilled water for 20 minutes. To evaluate seed germination under different concentrations of Artemisia sieberi and Salvia syriaca extracts, 25 seeds were placed in petri dishes containing a filter paper (every replication included 100 seeds in four petri dishes). Five $\mathrm{ml}$ of different concentrations were added to each petri dish. Distilled water was used as control treatment. The samples were then placed in a growth chamber under the conditions of darkness and $25^{\circ} \mathrm{C}$ temperature. The seeds were classified as germinated when root protrusion occurred as much as $2 \mathrm{~mm}$. Germination speed was determined, using the following equation:

$$
\mathrm{R}=\frac{\sum \mathrm{n}}{\sum(\mathrm{D} . \mathrm{n})}
$$

Where, $\mathrm{n}$ is the number of germinated seeds on day $\mathrm{D}$, and $\mathrm{D}$ is the number of days from the start of the test. Seedling grew for 7 days after germination occurrence. To evaluate the effect of two medicinal plant extracts on seedling growth properties of purslane, leaf length, leaf width, leaf number, leaf mass, stem length and stem mass were measured.

Supplementary experiment was carried out in an experimental field in Shushtar (Latitude $32^{\circ} 30 / \mathrm{N}$, Longitude $48^{\circ} 20 / \mathrm{E}$, and altitude $150 \mathrm{~m}$ above sea level), Iran during 2014-2015 growing season. The experiment was factorial $(2 \times 5)$ and based on randomized complete block design with four replications. The treatments included medicinal plant species (Artemisia sieberi and Salvia syriaca) and the amount of residue mixed with soil $\left(0.0,1.0,2.0,3.0\right.$ and $4.0 \mathrm{~g} \mathrm{~kg}^{-1}$ soil). The previous crop of experimental site was wheat. After harvesting and field plowing, wheat remains were removed from the field. Purslane seeds $\left(6\right.$ plants $\left.\mathrm{m}^{-2}\right)$ were sowed in the depth of $0.5 \mathrm{~cm}$. Each plot contained 6 rows with the length of $2 \mathrm{~m}$. The distance between two consecutive rows was $20 \mathrm{~cm}$ (Farahmand, 2011). After four months, purslane was harvested. For this purpose, 15 plants were harvested from middle rows. The plants were placed in a plastic bag and were transported to laboratory. After that, shoot dry mass, plant number per unit area, seed number per capsule, capsule number per plant and seed production $\left(\mathrm{kg} \mathrm{ha}^{-1}\right)$ were determined.

Analysis of variance of the data and mean comparison (according to Duncan's multiple range test) were carried out, using MSTATC statistical software.

\section{RESULTS AND DISCUSSION}

The results of the laboratory experiment showed that the main effects of plant species and concentration of their whole plant extracts on seed germination and early seedling growth of purslane were significant $(P \leq 0.01)$. However, the interaction of plant species $\times$ extract concentration was not significant $(\mathrm{P} \leq 0.01)$. The extracts of Artemisia sieberi and Salvia syriaca considerably $(\mathrm{P} \leq 0.01)$ reduced the percentage and seed germination speed of purslane. Our results showed that inhibitory effect of Artemisia sieberi on purslane germination performance was stronger compared to Salvia syriaca. Compared to control treatment, Artemisia extract reduced seed germination and germination speed by $57 \%$ and $54 \%$ compared to significantly lower effect in Salvia with $44 \%$ and $47 \%$, respectively (Table 1). Our results displayed that the increase in plant extract concentration led to stronger reduction in seed germination and germination speed. In terms of plant extract concentration level effect, the differences in germination and germination speed between the highest $(20 \%)$ and the lowest (control) extract concentrations were $73.5 \%$ and $70 \%$, respectively (Table 1).

Purslane seedling growth parameters including leaf length, leaf number, leaf mass, leaf width, stem length and stem mass were greatly reduced by Artemisia sieberi and Salvia syriaca extracts. The negative effect of Artemisia sieberi on seedling growth of purslane was stronger compared to Salvia syriaca (Figure 1). 
Seyed Nader MOUSAVIAN et. al

Table 1: Effect of plant species and concentration level of Artemisia sieberi Bess. and Salvia syriaca L. extracts on germination percentage and speed of purslane (Portulaca oleraceae L.) seed

\begin{tabular}{cccc}
\hline Treatment & Control & $\begin{array}{c}\text { Germination } \\
\text { percentage }\end{array}$ & $\begin{array}{c}\text { Germination } \\
\text { speed }\end{array}$ \\
\hline Plant species & $61.25 \mathrm{a}$ & $6.43 \mathrm{a}$ \\
& $\begin{array}{c}\text { Artemisia sieberi } \\
\text { Bess. }\end{array}$ & $26.25 \mathrm{c}$ & $2.94 \mathrm{c}$ \\
& Salvia syriaca L. & $34.38 \mathrm{~b}$ & $3.43 \mathrm{~b}$ \\
\hline Plant extract & 0.0 & $61.25 \mathrm{a}$ & $6.43 \mathrm{a}$ \\
Concentration (\%) & 5.0 & $41.25 \mathrm{~b}$ & $4.31 \mathrm{~b}$ \\
& 10.0 & $34.38 \mathrm{c}$ & $3.5 \mathrm{bc}$ \\
& 15.0 & $29.38 \mathrm{~d}$ & $3.0 \mathrm{c}$ \\
& 20.0 & $16.25 \mathrm{e}$ & $1.94 \mathrm{~d}$
\end{tabular}

Different letters in each column for each trait indicates significant difference according to Duncan's multiple range test.
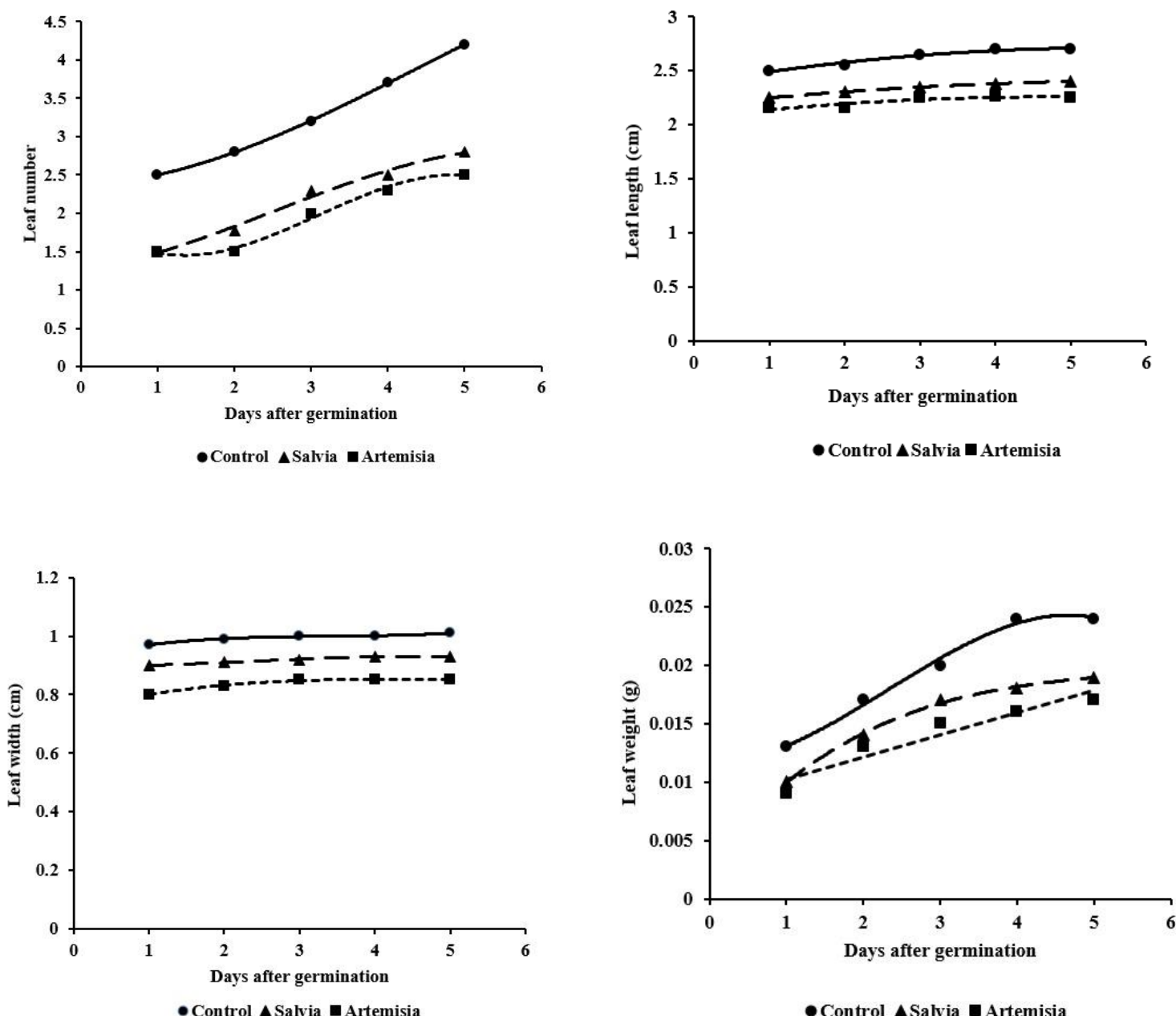

Control $\mathbf{\Delta}$ Salvia $\mathbf{a r t e m i s i a}$ 

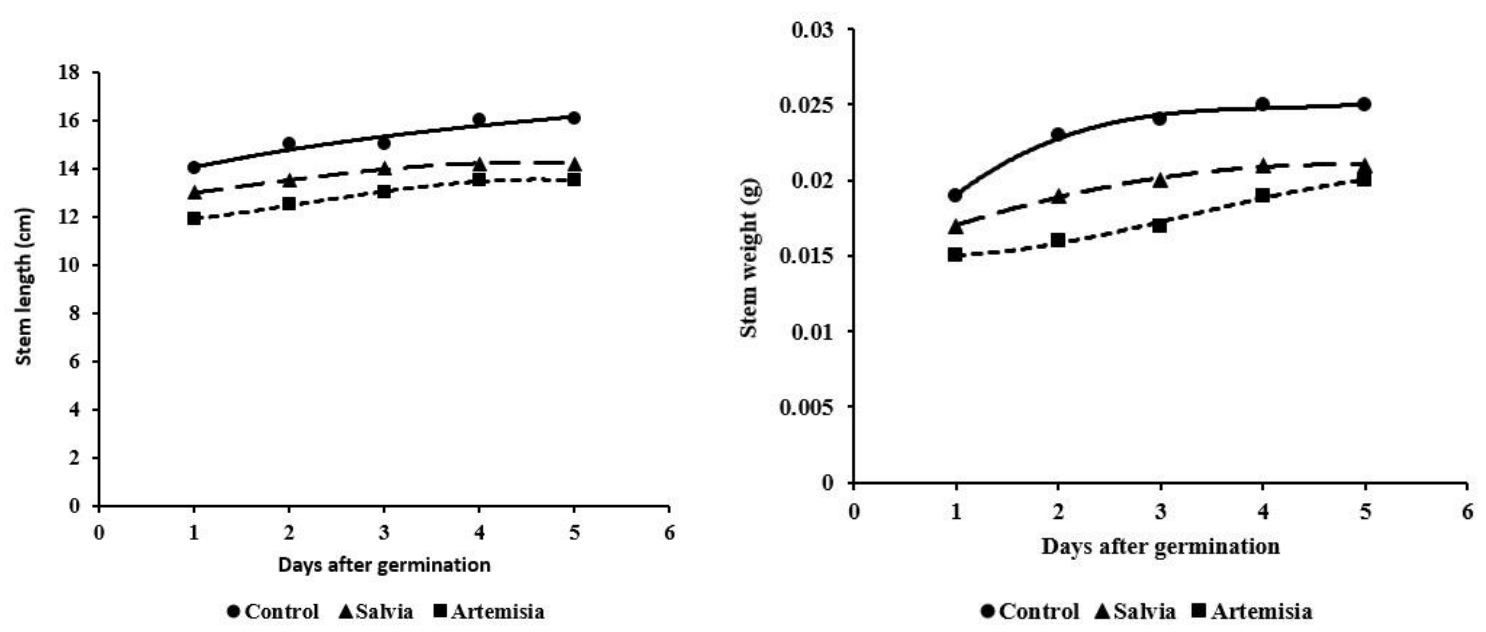

Figure 1: Effect of plant species on leaf and stem growth properties of purslane (Portulaca oleraceae L.) after seedling emergence.

The upsurge in extract concentration was accompanied by higher reduction in leaf and stem growth of purslane. The highest and the lowest leaf number, leaf width, leaf mass, leaf length and stem mass were observed in control and the concentration of $20 \%$, respectively (Figure 2).

The results of field experiment showed that the effect of mixing residue with soil was noteworthy $(\mathrm{P} \leq 0.01)$ on capsule number per plant, seed number per plant, seed number per unit area, seed production and shoot dry mass of purslane. However, seed number per capsule and 1000 -seed mass were not significantly $(\mathrm{P} \leq 0.01)$ influenced by the mixture of plant residues and soil treatment. The highest seed production $\left(\mathrm{kg} \mathrm{ha}^{-1}\right)$ was observed in control treatment. The purslane weed had the lowest seed production in the treatment of $4.0 \mathrm{~g} \mathrm{~kg}^{-1}$ mixture of residues with soil (Table 2). 

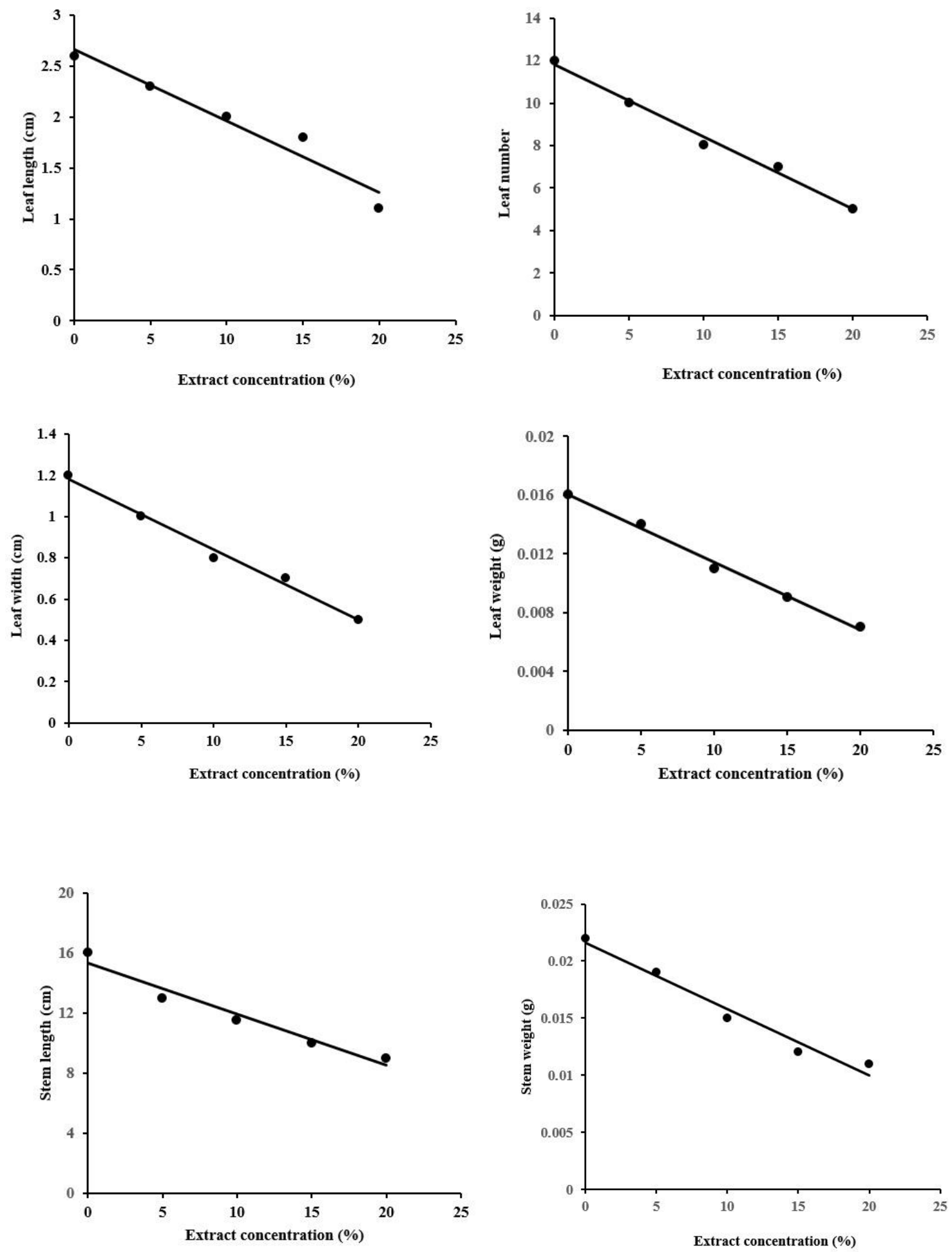

Figure 2: Effect of plant extract concentration (\%) on leaf and stem growth properties of purslane (Portulaca oleraceae $\mathrm{L}$.) after seedling emergence 
Allelopathic effect of two medicinal plants on seed germination, ... of purslane (Portulaca oleraceae L.) weed

Table 2: Effect of plant residues and soil mixture type on growth and seed production of purslane (Portulaca oleraceae $\mathrm{L}$.) under field conditions

\begin{tabular}{cccccc}
\hline $\begin{array}{c}\text { Treatment (mixture of } \\
\text { plant residues and } \\
\text { soil) }\left(\mathrm{g} \mathrm{kg}^{-1}\right)\end{array}$ & $\begin{array}{c}\text { Plant number/ } \\
\text { unit area }\end{array}$ & $\begin{array}{c}\text { Shoot dry } \\
\text { mass }(\mathrm{g})\end{array}$ & $\begin{array}{c}\text { Capsule } \\
\text { number/ } \\
\text { plant }\end{array}$ & $\begin{array}{c}\text { Seed } \\
\text { number/ } \\
\text { capsule }\end{array}$ & $\begin{array}{c}\text { Seed production } \\
\left(\mathrm{kg} \mathrm{ha}^{-1}\right)\end{array}$ \\
\hline Control & $20.0 \mathrm{a}$ & $38.3 \mathrm{a}$ & $9.7 \mathrm{a}$ & $211.3 \mathrm{a}$ & $12.1 \mathrm{a}$ \\
1 & $13.0 \mathrm{~b}$ & $26.8 \mathrm{~b}$ & $9.1 \mathrm{ab}$ & $141.0 \mathrm{ab}$ & $6.0 \mathrm{~b}$ \\
2 & $9.5 \mathrm{bc}$ & $21.67 \mathrm{c}$ & $7.7 \mathrm{ab}$ & $172.8 \mathrm{ab}$ & $5.3 \mathrm{~b}$ \\
3 & $7.17 \mathrm{bc}$ & $16.83 \mathrm{~d}$ & $6.2 \mathrm{bc}$ & $93.3 \mathrm{bc}$ & $2.4 \mathrm{bc}$ \\
4 & $5.17 \mathrm{c}$ & $12.17 \mathrm{e}$ & $3.2 \mathrm{c}$ & $49.3 \mathrm{c}$ & $0.98 \mathrm{c}$
\end{tabular}

Numbers in different treatment mixtures indicate dry mass ( $\mathrm{g}$ ) of plant residues (Artemisia and salvia) per kg of fresh soil mass.

Different letters in each column for each trait indicates significant difference between them at $\mathrm{P} \leq 0.01$ according to Duncan's multiple range test.

In the current experiment, the inhibitory effect of Artemisia sieberi was higher than that of Salvia syriaca which is compatible with the finding by Jafarpour et al. (2011) who reported that while seed germination of bean was not affected by low extracts of Salvia syriaca, all concentrations of Artemisia sieberi reduced germination and seedling growth of bean. Lydon et al. (1997) found that low concentration of Artemisia sieberi reduced seed germination and seedling growth of Sinapis arvensis L. weed, but had no effect on wheat, suggesting that Artemisia sieberi extract can be used for weeds control. The results of the present research revealed that Artemisia sieberi was more efficient in reducing purslane growth. However, the two crops have the potential for being applied for purslane weed control, where they not only reduced seed germination of purslane but also seed germination and seedling growth were delayed considerably. It has been emphasized that the delay in germination has negative impacts on seedling growth, where production of small seedlings reduces the competition ability of purslane (Chon et al., 2005).

Pinene, salween and tannins are allelopathic compounds found in Salvia syriaca extract (Kohli et al., 2001) which denature mitochondrial structure, leading to inability of cells to use their storage materials (Mighati, 2003). This finally decreases purslane root and shoot growth. Inhibitory effect of Salvia syriaca on enzymatic activity, such as $\alpha$-amylase, is another factor reducing seed germination (Ghomi \& Tavili, 2011). There are some allelopathic compounds in Artemisia sieberi extract which inhibit cell division and elongation and, therefore, seed germination and seedling growth of purslane (Gholami et al., 2012). It has been reported that Artemisia sieberi has biological compound artemisinin which has toxic effects on plant seed germination
(Lydon et al., 1997). The results of the research by Ghorbani et al., (2008) revealed that Artemisia sieberi extract decreased germination and seedling growth of Avena fatua L. and Amaranthus retroflexus L. which is in line with the findings of the present experiment.

When the share of Artemisia and salvia residues increased in plant soil mixture, purslane weed produced lower dry matter (Table 2). Medicinal plant residues, especially in the treatment of $4.0 \mathrm{~g} \mathrm{~kg}^{-1}$ mixture of residues with soil, led to a smaller number of emerged and established purslane plants, which is analogous with our laboratory findings in which germination percentage and speed of purslane seeds were negatively affected by Artemisia and salvia extracts (Table 1). Purslane showed $30 \%, 43 \%, 56 \%$ and $69 \%$ reduction in shoot dry mass in the $1.0,2.0,3.0$ and $4.0 \mathrm{~g} \mathrm{~kg}^{-1}$ treatments, respectively. Similar results were reported by Erez and Fiden (2015) who found that germination of Portulaca oleraceae seeds was inhibited by extract of Salvia macrochlamys Boiss. \& Kotschy.

Since the impact of residue mixing treatments was not substantial on 1000 -seed mass, it can be concluded that reduction of seed production of purslane $\left(\mathrm{kg} \mathrm{ha}^{-1}\right)$ resulted from the decrease in the number of seeds per unit area. On the other hand, seed number per capsule was not significantly affected by field experimental treatments, thus, lower seed number per unit area was induced by lower capsule number per unit area. In fact, allelopathic effects of Artemisia sieberi and Salvia syriaca reduced seed germination of purslane which induced lower plant per unit area and, finally, seed production. Seed production of $1.0,2.0,3.0$ and $4.0 \mathrm{~g}$ $\mathrm{kg}^{-1}$ residue treatments was $35 \%, 53 \%, 64 \%$ and $74 \%$ lower compared to control treatment, indicating considerable decrease of purslane seed production 
affected by addition of artemisia and salvia plant residues in soil. Generally, Artemisia sieberi and Salvia syriaca residues can be successfully utilized for nonchemical control of purslane. However, the effects of allelo-chemicals of these two medicinal plants on the growth and yield of other crops need more investigation.

\section{REFERENCES}

Behdad, A., Abrishamchi, P. and Jangjo, M. (2008). Allelopathic effects of (Artemisia aucheri) on germination (Bromus tomentellus).Proceeding of First National Congress on Plant Biology. pp 301309. 15 March 2008. Teheran.

Cavigelli, M.A., Hima, B.L., Hanson, J.C., Teasdale, J.R., Conklin, A.E. and Lu YC. (2009). Long-term economic performance of organic and conventional field crops in the mid-Atlantic region. Renewable Agriculture and Food Systems, 24, 102-119. doi:10.1017/S1742170509002555

Chon, S.U., Jang, H.G., Kim, D.K., Kim, Y.M.M, Boo, H.O. and Kina, Y.J. (2005). Allelopathic potential in lettuce (Lactuca sativa) plants. Scientia Horticulturae, 106, doi:10.1016/j.scienta.2005.04.005

Demden, F.H. and Liewellyn, R.S. (2006). No tillage adoption decision in south Australian copping and the role of weed management. Australian Journal of Experimental Agriculture, 46, 563-569. doi:10.1071/EA05025

Erez, M. E and Fiden, M. (2015) Allelopathic effects of sage (Salvia macrochlamys) extract on germination of Portulaca oleracea seeds. Allelopathy Journal, 35 (2), 285-296.

Farahmand, M. (2012). Effect of planting date and arrangement on agronomical and yield of purslane under Ahwaz weather condition. MS thesis. Faculty of Agriculture, University of Shahrekord. ShahreKord, Iran. (In Persian with English abstract).

Gherekhloo, J., Noroozi, S., Mazaheri, D., Ghanbari, A., Ghannadha, M.R., Vidal, R.A. and De-Prado, R. (2010). Multispecies weed competition and their economic threshold on the wheat crop. Planta Daninha, 28, 239-246. doi:10.1590/S010083582010000200002

Gholami, P., Ghorbani, J. and Ghader, S. (2011). Allelopathic effects of Artemisia aucheri on seed germination and Dactylis glomerata properties of Festuca arundinacea Schreb. Plant Ecophysiology, 2(1), 43-52. (In Persian with English abstract).

Ghomi, S. and Tavili, A. (2012). Inhibitory effect of Salvia sclarea on some germination properties of
Bromus timentellus. Journal of Seed Science and Technology, 1(2), 193-202.

Ghorbanli, M., Bakhshi-Khaniki, G.R. and Shojaie, A. A. (2008). Examination of the effects of allelopathy of Artemisia sieberi Besser subsp.sieberi on seed germination and Avena lodoviciana and Amaranthus retroflexus seedlings growth. Pazoohesh and Sazandegi, 79, 129-134. (In Persian with English abstract).

Hassan pour, H. and Azizi, M. (2007). Allelopatic effects medicinal plants on weed control. Proceeding of Third National Congress on Medical Plants. pp 45- 48. 25 May 2007. Teheran. (In Persian with English abstract).

Holander, N.G., Bastiaans, L. and Kropff, M.J. (2007). Clover as a cover crop for weed suppression in an intercropping design I. Characteristics of several clover species. European Journal of Agronomy, 26, 92-103. doi:10.1016/j.eja.2006.08.011

Jafarpour, R., Tajbakhsh, M. and Ivazi, A.R. (2011). Allelopathic effects of white mustard, yellow yarrow, Artemisia, Salvia and juglan leaf on red bean. Iranian Journal of Field Crops Research, 9 (1), 39-49. (In Persian with English abstract).

Jefferson, L.V. and Pennachiom, M. (2003). Allelopathic of foliage extracts from four Chenopodiaceae species on seed germination. Journal of Arid Environment, 55, 273-285. doi:10.1016/S0140-1963(03)00028-4

Kohli, R.K, Singh, H.P and Batish, D.R. (2001). Allelopathy in agroecosystems. Food Products Press. USA.

Kropff, M.J and Walter, H. (2000). EWRS and the challenges for weed research at the start of a new millennium. Weed Research, 40, 7-10. doi:10.1046/j.1365-3180.2000.00166.x

Lydon, J., Teasdale, J.R. and Chen, P.K. (1997). Allelopathic activity of annual wormwood (Artemisia annua L.) and the role of artemisinin. Weed Science, 45, 807-811.

Mighati, F. (2003). Allelopathy, concepts and application. Paro press. Tehran, Iran. (In Persian with English abstract). 
Moghimi, J. (2005). Introduction of some pasture species for pasture improvement. Arvan press. Tehran, Iran. (In Persian).

Piraste, H., Emam, H. and Saharkhiz, M. J. (2011). Evaluation of allopathic effects of some species on germination and seedling early growth of wheat and wild oat. Iranian Journal of Field Crops Research, 9 (1), 95-102. (In Persian with English abstract).

Qasem, J.R. and Hill, T. A. (1989). Possible role of allelopathy in the competition between tomatoes. Weed Research, 29, 349-356. doi:10.1111/j.13653180.1989.tb01305.x

Samad, M.A., Rahman, M.M., Hossaini, A.K., Rahman, M.S. and Rahman, S.M. (2008). Allelopathic effects of five selected weed species on seed germination and seedling growth of corn. Journal of Soil Nature, 2, 13-18.

Samadani, B.M. and Baghestani, V. A.(2005). Allelopathic effect of Artemisia on wild oat. Pajoohesh and Sazandegi, 68, 69-74. (In Persian with English abstract).

Yuan-Quan, C., Peng, S., Chen, L. and Xue-peng, S. (2012). Xanthium suppression under maizesunflower intercropping system. Journal of Integrated Agriculture, 11(6), 1026-1037. doi:10.1016/S2095-3119(12)60095-1 